Transportation Management (2018) Volume 1 doi:10.24294/tm.v1i3.798

\title{
Cluster Model of Supply Chains Management and Development of Transport-logistics Infrastructure
}

\author{
Antonyuk Victor $\mathbf{S}^{\mathbf{1}}$, Smerichevska Svitlana $V^{2}$, Remyha Yuliia $\mathbf{S}^{\mathbf{3}}$ \\ ${ }^{1}$ Dr. of Technical Sciences, Professor, National Technical University "Kiev Polytechnic Institute”, Kyiv, Ukraine \\ ${ }^{2}$ Dr. of Economical Sciences, Professor, National Aviation University, Kyiv, Ukraine \\ ${ }^{3}$ Candidate of Economical Sciences, Associate Professor, National Aviation University, Kyiv, Ukraine
}

\begin{abstract}
The article focuses on the strategic role and peculiarities of the cluster innovative structures formation for ensuring competitiveness and economic development. Based on the generalization of the cluster theory evolution and taking into account the current state of the world economic development, the expediency of a new fundamentally approach to the formation and development of clusters as an effective form of supply chain management and ensuring their competitiveness have been substantiated. The place of clusters infrastructure type in the supply chains management has been determined. The characteristic of modern properties, strategic role, goals and priority tasks of transport-logistics clusters of an innovative type in providing the transport-logistic infrastructure development and formation of perfect supply chains have been presented. The systematic presentation presents the advantages, disadvantages, and risks of cluster organizational management forms and their impact on the competitiveness of supply chains. The efficiency of cluster structures has been analyzed. The directions and sources for obtaining synergistic effect from the interaction of supply chain participants in cluster structures have been determined. The probability of obtaining the "value added" effect in cluster structures has been proved. The strategic prospects of transport-logistics clusters development in Ukraine have been determined.
\end{abstract}

Keywords: Cluster; supply chain; transport-logistics cluster; transport-logistics infrastructure; economic development; efficiency; synergy effect; strategic perspectives

\section{Introduction}

In current conditions, according to M. Porter, compete not individual companies but supply chains in which they are integrated. Therefore, the issues of finding effective organizational forms of supply chain management are becoming of particular importance today, which would ensure the formation of perfect supply chains and creation of additional consumer value of goods and services. One of these organizational forms should be considered cluster organizational structures, whose strategic role in the formation of perfect supply chains, unfortunately, is still underestimated, although clusters, as an effective form of public-private partnership, successfully operate in most developed countries of the world. For Ukraine, which is on the path of a radical restructuring of the domestic economic system, the cluster structuring of the economy becomes of strategic importance. A special role in supply chain management plays such cluster infrastructure as transport-logistics clusters.

\section{Strategic role and features of cluster structures for economic development}

\subsection{Clusters and Competitiveness}

Cluster policy in the world's leading countries is seen as key to increasing competitiveness. Unfortunately, in Ukraine, insufficient attention is being paid to the formation of clusters as an organizational form of ensuring effective business interaction and an effective mechanism of public-private partnership. However, it is fair to say that the term "cluster development" is increasingly used in the development of strategic documents for the socio-economic

\footnotetext{
Copyright (C) 2018 Antonyuk Victor S et al.

doi: $10.24294 /$ tm.v1i3.798

EnPress Publisher LLC.This work is licensed under the Creative Commons Attribution-NonCommercial 4.0 International License (CC BY-NC 4.0).

http://creativecommons.org/licenses/ by/4.0/
} 
development of regions and individual industries in Ukraine. In particular, the "National Transport Strategy of Ukraine for the period up to 2030" recognizes the need for the construction of multimodal transport and logistics terminals and the formation of transport-logistics clusters (TLC) around them, to solve many problems of the transport industry and the development of transport infrastructure ${ }^{[1]}$.

The world experience of developed countries convincingly proves the efficiency and regularity of the emergence of different types of clusters. In recent years, the formation of clusters has become an important part of state policy. The "EU cluster manifesto" adopted by the European Commission in Brussels in February 2007 and the "European Cluster Memorandum", signed in Stockholm in January 2008, identified cluster development as the main mechanism for improving the competitiveness of the EU's economies, identifying relevant priorities for national programs. The principle of clustering is widely used in most EU countries, effectively implemented at the national, regional, and municipal levels. For example, the Dutch economy comprises 20 clusters, in Denmark, $40 \%$ of enterprises provide $60 \%$ of exports, they also operate as clusters, and in Austria, there are cross-border similar entities with Hungary, Italy, Switzerland, and Germany. The cluster approach is widely used in the economies of Germany, USA, Japan, Finland, China, India and a number of other countries. In general, the processes of transport-logistics clustering in the European Union today consider the possibility of forming a single pan-European transport-logistics space ${ }^{[10]}$.

According to the report of the Ministry of Economic Development of Ukraine in 2016, 42 clusters are registered in Ukraine, specializations of which are: information technologies, engineering, agriculture, energy, transport. At the same time, content analysis of information resources allows us to find online representations of only 5 clusters, which is a vivid illustration of the level of their real work.

Despite the wide coverage of the clusters theory and various aspects of the transport-logistics systems creation by domestic and foreign researchers, the question of the TLC formation, the study of world experience in building cluster models of the economy, aspects of cluster policy at the general economic and sectoral levels becomes of particular relevance in the conditions of a complete reboot of the national economy management system in Ukraine.

\subsection{Evolution of cluster theory development}

Since 1890, when the British economist and founder of Cambridge School Alfred Marshall[ ${ }^{[2]}$ pointed out the importance of industry clusters, many researchers and strategists tried to identify the factors contributing to the success of different cluster associations. In the late 1990s, business strategist Michael Porter argued that industries are becoming more competitive due to clusters since clusters help accelerate the pace of innovation and create new businesses ${ }^{[3]}$.

The ideas of Porter, Weber, Marshall, Scott and other economists' works are the theoretical core that allows us to justify the logic and regularity of world politics of clustering the economy.

Based on the review of the current economic literature on the cluster structures development revealed that currently does not exist as a unified approach to the formation of clusters, and so no unity in the definition of the essence of economic categories "cluster". Different scientists interpret the economic essence of the cluster in different ways, focusing on certain features: territorial localization, a concentration of production, the existence of ties based on common interests, competition, and specialization in a particular area of activity, complementarity, and others. In addition, these definitions are in some development processes as the cluster theory develops.

Analyzing various authors' interpretations of the term "cluster", we can draw some conclusions:

1) there is a great variety of definitions of copyright essence of the term "cluster", but relatively conceptual traced their unity. This is explained by the fact that the main theoretical basis on which the researchers of cluster structures rest is the concept of M. Porter and his followers;

2) in their definitions, both domestic and foreign economists, as the main characteristics of clusters allocate its territorial localization or geographic concentration and a certain way of the relationship of the cluster structures members (either vertically, either horizontally, or vertically and horizontally).

\subsection{Cluster as an effective form of supply chain management and ensuring its competitiveness}

To our mind, at this stage of clusterization development, focusing only on regional boundaries of the formation and activity of clusters is no longer relevant. In a context of globalization and intellectualization of the economy, a cluster is 
not just a form of enterprise unification, it is an effective organizational form of supply chain management, which is created to improve the management of material, financial, information, service flows, contributing to the development and growth of economic potential as separate business units of the cluster, and certain territories on which they are placed. After analyzing different points of view on the functioning of clusters, we propose to disclose the essence of the cluster through the interconnection of the organizations that are part of it and whose activities represent a chain of value added. However, it should be noted that not everyone cluster can be a supply chain (network), but each supply chain, which has a relatively high spatial localization can be considered as a cluster.

The characteristic and generalization of the essential properties of the cluster ${ }^{[4-6]}$, allowed to form the author's definition of this economic category. In our opinion, the cluster is a unique complex, the newest organizational form of supply chain management, which ensures the formation of efficient integrated logistics systems that have a high level of adaptability, the existence of a single institutional environment and information space.

The cluster, as an organizational form of supply chain management, is created with the aim of increasing the efficiency of technological chains management of freight flows movement from suppliers of raw materials, industrial structures to consumers that interact within a single stream process, contributing to the creation of additional consumer value of goods and services, development and growth of logistics potential in certain territory, the formation of perfect and competitive supply chains.

According to this research, major European clustering results have been identified and shown in Figure 1.

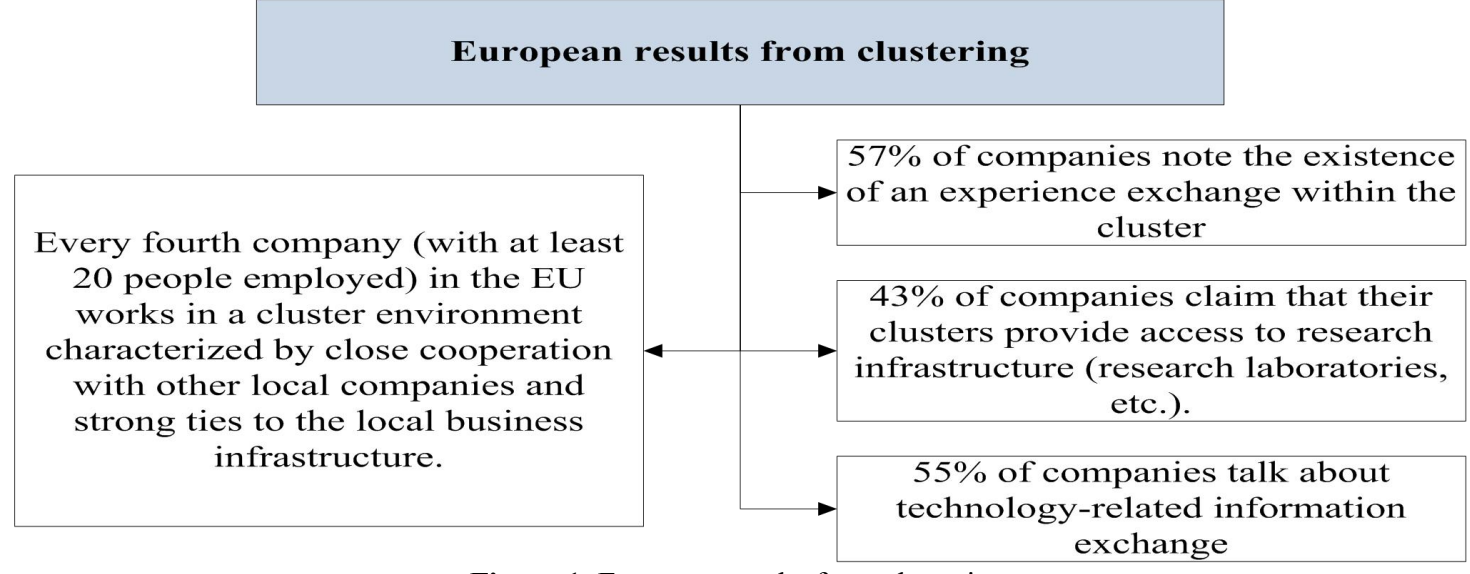

Figure 1; European results from clustering.

Source: Developed by materials ${ }^{[7,8]}$

An important feature of the cluster is the innovation orientation factor. Clusters are usually formed where the "breakthrough" in the field of technology or production technology and the subsequent entry into new market niches is being implemented or expected. In this regard, many countries - both economically developed and those that form a market economy - increasingly use a cluster approach in support of the most promising areas and forms of entrepreneurial activity, in the formation and regulation of their innovation systems.

In connection with the expansion of globalization processes in the economy, clusters have become widespread in many countries, both developed economies and developing countries. As a result, there is a large variety of clusters today in the world.

\subsection{Global model of cluster structures}

Specialists from the international organizations of UNIDO, which appeared in 1966, in accordance with the UN decision, provide analytical support for the cluster's development. It was assigned the role of the central coordinating body in the field of industrial development within the UN system, as well as the task of promoting industrial development at the global, regional and national levels as well as at sectoral levels. Since 1993, UNIDO has developed a set of recommendations to help regional governments and the private sector to interact with the development and implementation of programs for the development of clusters and small business networks. During this 
time, the organization studies examples of successful enterprises clusters, methods of their formation, and technical cooperation in various developing countries: India, Indonesia, Malaysia, Mexico, Nicaragua, Honduras, Jamaica, Bolivia, Madagascar, and Morocco.

\begin{tabular}{|c|c|}
\hline Parameters & Characteristic \\
\hline \multicolumn{2}{|r|}{ American model of cluster development (USA) } \\
\hline State support & $\begin{array}{l}\text { Joint activity of state structures, industrial enterprises and academic organizations; development of } \\
\text { scientific and technological partnership; provision of tax credits and preferential taxes; attraction of } \\
\text { primary capital }\end{array}$ \\
\hline Business model & $\begin{array}{l}\text { Concentration of enterprises in one region and maximum use of natural, scientific, personnel and } \\
\text { integration potential }\end{array}$ \\
\hline Types of clusters & Information technology, film industry, automotive, aerospace \\
\hline \multicolumn{2}{|r|}{ European model of cluster development } \\
\hline \multicolumn{2}{|r|}{ Italy } \\
\hline State support & $\begin{array}{l}\text { The state policy of the cluster organization is carried out at the level of local self-government, which } \\
\text { provides support for the creation of new enterprises and cooperation between individual producers, } \\
\text { attracting investors, granting preferences for the export of goods; regulation of the labor market. }\end{array}$ \\
\hline Business model & $\begin{array}{l}\text { Concentration of small and medium-sized firms in a certain area, combined into different } \\
\text { assignments; flexible and equal cooperation of enterprises }\end{array}$ \\
\hline Types of clusters & Furniture and interior, food, light industry, etc. \\
\hline \multicolumn{2}{|r|}{ France } \\
\hline State support & $\begin{array}{l}\text { Purposeful regulation of innovation activity; stimulating R\&D for industry needs; budget allocations } \\
\text { for high-tech types of business; reduction of taxes on R\&D investment }\end{array}$ \\
\hline Business model & Concentration of enterprises around a large company \\
\hline Types of clusters & Perfumery, cosmetics, textiles, food, wines, etc. \\
\hline \multicolumn{2}{|r|}{ Finland } \\
\hline State support & $\begin{array}{l}\text { The state is in close contact with the business sector, but without broad penetration into the structure } \\
\text { of large private industrial enterprises. }\end{array}$ \\
\hline Business model & Interaction of large, medium and small enterprises \\
\hline Types of clusters & Chemical, printing, machine-building, electrical equipment, furniture \\
\hline \multicolumn{2}{|r|}{ Germany } \\
\hline State support & $\begin{array}{l}\text { Consolidating the efforts of industry and research centers. There are three types of clusters: } \\
\text { scientific, which transfer their technology into production; combining research and production; } \\
\text { clusters that arise on the basis of innovative firms. Financial resources are obtained from industrial } \\
\text { clusters from federal and local sources }\end{array}$ \\
\hline Business model & Interaction of large, medium and small enterprises \\
\hline Types of clusters & $\begin{array}{l}\text { Chemical, printing, cluster for the production of transport equipment, cluster in the automotive } \\
\text { industry }\end{array}$ \\
\hline \multicolumn{2}{|r|}{ Asian model of cluster development (Japan) } \\
\hline State support & $\begin{array}{l}\text { Encouragement of the development of highly specialized regions; attracting from abroad modern } \\
\text { technologies }\end{array}$ \\
\hline
\end{tabular}




\begin{tabular}{|c|l|}
\hline Business model & $\begin{array}{l}\text { The Japanese cluster consists of one main enterprise that uses services of two or three levels of } \\
\text { subcontractors that are located in a geographical proximity to it }\end{array}$ \\
\hline Types of clusters & Electrotechnical, automotive, etc. \\
\hline
\end{tabular}

Table 1. World practice of cluster structures development

Source: Based on materials 10-11

\section{The location clusters of infrastructure type in the supply chains management}

A special role in cluster models of economic development and supply chain management belongs to clusters of infrastructure type, among which TLC, of course, occupy a special place. For Ukraine, which has a colossal transit potential, the TLC development is a strategic importance.

\subsection{The role of transport in the economy of Ukraine}

The transport networks of Ukraine are among the largest in Europe. Due to the advantageous geographic position of the country, 5 international transport corridors pass through the territory of Ukraine, the total length of which is 5 thousand $\mathrm{km}$.

The transport sector makes a significant contribution to the Ukrainian economy. Transport, warehousing, postal and courier activities totally provide $6.6 \%$ of GDP (2016) and employment of about 1 million people (about $6 \%$ of the able-bodied population). In addition, Ukrainian transport companies provided $6.1 \%$ of the country's budget revenues in 2015. In 2015, about 7.3 million USD (or 8.2\%) of Gross Value Added (GVA) of Ukraine was produced in the transport, warehousing, postal and courier activities [1, p.34]. While in 2016 in $28 \mathrm{EU}$ countries on transport and warehousing (including postal and courier activities) accounted for about $5.1 \%$ of total GDP.

Agriculture (27.3\%), metallurgical production (10.7\%), oil and gas (10.7\%), coal (6.8\%), retail trade (12.4\%), communications and postal services (6.3\%), public administration and defense $(7 \%)$ are the most dependent sectors of transport in Ukraine.

Transport is important for foreign trade, where transport accounts for $12.1 \%$ of exports and $15.3 \%$ of import $\operatorname{costs}^{[1]}$.

Experts estimate that the transport industry in Ukraine needs significant investments (more than 30 billion USD) to meet the economic needs of producers, to ensure the efficiency and safety of transport services. Priorities should be optimization, improvement, modernization, and development of transport infrastructure and transport and logistics services. There is a risk that the potential and quality of transport infrastructure can become a barrier to Ukraine's economic development. It is precisely in order to avert this risk that fundamental conceptual changes in the transport sector and transport infrastructure development strategy of Ukraine are needed. The main conceptual idea of the National transport strategy of Ukraine until 2030 is the development of multimodal technologies and intelligent transport systems, network of logistics centers and intermodal terminals, diversification of routes and transport corridors, development of the concept of a single window, optimization of transport and logistics costs in the supply chain of products to the end user, integration the national transport network to the pan-European TEN-T. All this requires an effective mechanism for ensuring the effectiveness of interaction between the state, business, science and education, which is possible on the basis of the development of transport-logistics clusters, which not only ensure the effectiveness of public-private partnership in the transport sector, but also contributed to optimizing the transport component and minimizing transport-logistics costs in supply chains of agricultural products, metal, export and import products, etc.

\subsection{Modern properties and strategic role of transport-logistics clusters in the formation of} perfect supply chains

Today more and more clusters are formed at the intersection of major cargo flows and combined in a multitude of specialized facilities. The structure of such clusters is formed by organizations and enterprises, united by the only material, informational and financial flows. Such clusters involve the unification of separate regional, functional and 
economically interconnected logistics chains: international transport corridors, transport hubs of main infrastructure, transport and logistics centers, roads and highways in a single system that has the ability to provide high-quality transport and logistics services at a minimal cost ${ }^{[10]}$.

The world experience of the last decade provides quite a lot of examples of the formation and functioning of clusters in different segments of the regional and branch economies. Of great interest is developing to such a cluster as a transport-logistics cluster. Interest in TLC is due to a number of features of this category of economic clusters ${ }^{[4 ; 6 ; 11]}$ :

- $\quad$ TLC is a self-organizing structure, which is formed not on the basis of decision-making, but on the basis of cluster initiatives;

- TLC is a cluster of services that is significantly different from commodity production clusters. The attitude to clusters of services varies in connection with the development of the service sector;

- $\quad$ TLC is a cluster of two types of services (transport and logistics), each of which has its own special properties;

- TLC is a branch-infrastructure cluster, the level of development of which affects all sectors of the economy and spheres of life;

- $\quad$ TLC is a cluster of business competitiveness, the formation of which requires initiatives from both power and business;

- TLC is an innovative type cluster that stimulates the innovation activity of all its structural subsystems, the development of intelligent systems, and involves the need to create a powerful IT platform.

The peculiarity of the logistics cluster form is the transformation of relations between its participants on the organizational-planned, and not on a spontaneously-market basis. Transport clusters are formed at the intersection of the main freight flows and combine a variety of profile objects.

Active processes of merging business structures into clusters occur in EU countries, which, in particular, demonstrate the experience of establishing a network of transport-logistics clusters in Europe (Figure 2).

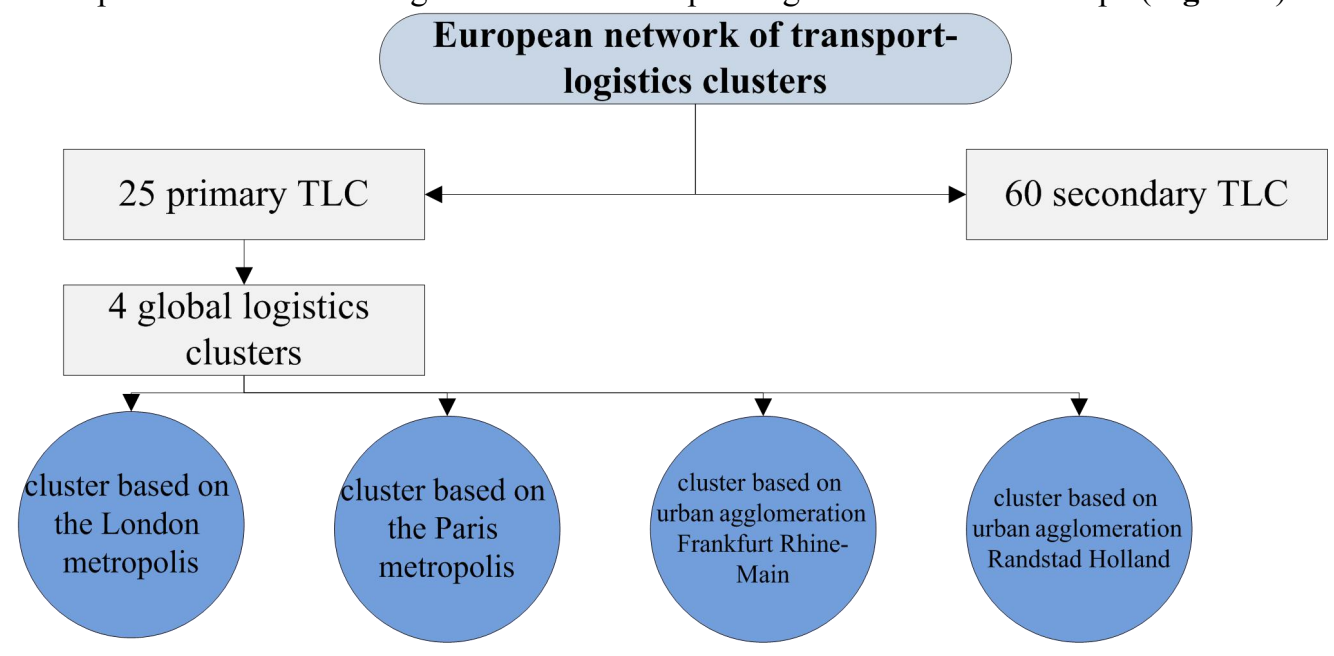

Figure 2; Modern processes of cluster-logistics transformation in EU countries.

Source: Developed by materials ${ }^{[12]}$

The demand for transport and logistics services in the European Union is 2.5 times faster than GDP, as the economies of the EU member states (and the further expansion of the EU) into a single economic space is integrated. The share of transport and logistics services provided by specialized providers in the total turnover reached $40 \%$. The main beneficiaries of this growth are Germany, Great Britain, and France, accounting for half of the total turnover ${ }^{[12]}$.

In spite of the cluster-forming activity initiated in Ukraine, unfortunately, in the country, unlike the reforming processes of the neighboring countries economies, both in the west - EU and in the east - CIS, to date there is no system legislation on the establishment of cluster support institutions in Ukraine ${ }^{[13]}$. For many years, market reforms have not yet adopted legislation regulating the clusters status and the participant's relationship, external partners, and the state. Currently, nobody actively initiates the adoption of the law on cluster associations. Meanwhile, in Ukraine, the 
central regulatory authorities have developed a regulatory framework for the formation of the state cluster policy principles which includes some projects.

Taking into account the passage through Ukraine of four out of ten Pan-European transport corridors $(3 ; 5 ; 7 ; 9)$ and four transcontinental transport corridors (Europe-Asia, TRACEKA, Baltic - Black Sea, Black Sea Transport Ring), and also extremely advantageous transit status of Ukraine (the highest transit rate among the European countries according to researches of the British institute Rendall) it is possible to talk about the creation on the territory of Ukraine a network of powerful transport-logistics clusters as an integral part of the TLC pan-European network ${ }^{[14]}$.

\subsection{Objectives and priority tasks of cluster structures for the development of transport-logistics infrastructure}

Creation of transport-logistics clusters should be guided by the achievement of the following objectives (Figure 3).

The analysis of the cluster characteristics allows us to assert that the priority tasks of the transport-logistics cluster should be:

- development and modernization of transport infrastructure (automobile and railways, river, sea and airports, objects of roadside service, points of supply, trade, parking lots, warehouses and distribution centers);

- creation of the modern multimodal terminals network, logistics centers, dry ports, terminals, specialized transshipment complexes, etc.;

- improvement of the construction mechanism, repair and maintenance of roads, its rational use;

- geographical expansion of the transportation scale;

- increasing the efficiency of internal logistics operations of freight transport by eliminating existing barriers and improving the relevant infrastructure, as well as its combination with the international and trans-European transport network TEN-T;

- increasing the share of container transportation and stimulate the development of piggyback transportations by creating favorable conditions for cargo owners and carriers, including at the legislative level;

- $\quad$ ensuring unified technological compatibility in the main directions of transportation and interconnections between modes of transport;

- stimulating innovation and introducing new technologies and intelligent systems into the transport-logistics industry.

Goals of transport-logistics clusters creation

Reducing costs and increasing the efficiency of knowledge-based services through synergies

Competitiveness increasing of the cluster participants by introducing innovations

Continuous recovery of transportlogistics infrastructure

Achieving a given level of quality logistics services in the region and optimizing logistics capacity
Optimization of cargo flows both in national and international supply chains

Formation of favorable conditions for creation of international transport corridors and other components of the structure

Development of partnership between the state and the private sector

Development and implementation of transport infrastructure development projects taking into account logistics clusterization

Figure 3; Goals of transport-logistics clusters creation.

Source: Own research 


\subsection{Benefits and risks of cluster organizational forms of supply chain management}

The use of a cluster as an organizational form of supply chain management can have both advantages and disadvantages and risks. The main ones are presented in Figure 4.

The cluster approach is a very popular area of the economic policy of countries with a high level of economic development. But one should be aware that the clustered approach to managing economies and supply chains, which domestic companies integrate, requires a prospect for at least five or seven years. The question arises, where is to start the development of clusters in Ukraine? First of all, from the formation of preparation the critical mass of managers for business, science, the public sector and local authorities who understand the phenomenon of the cluster, its advantages, and disadvantages.

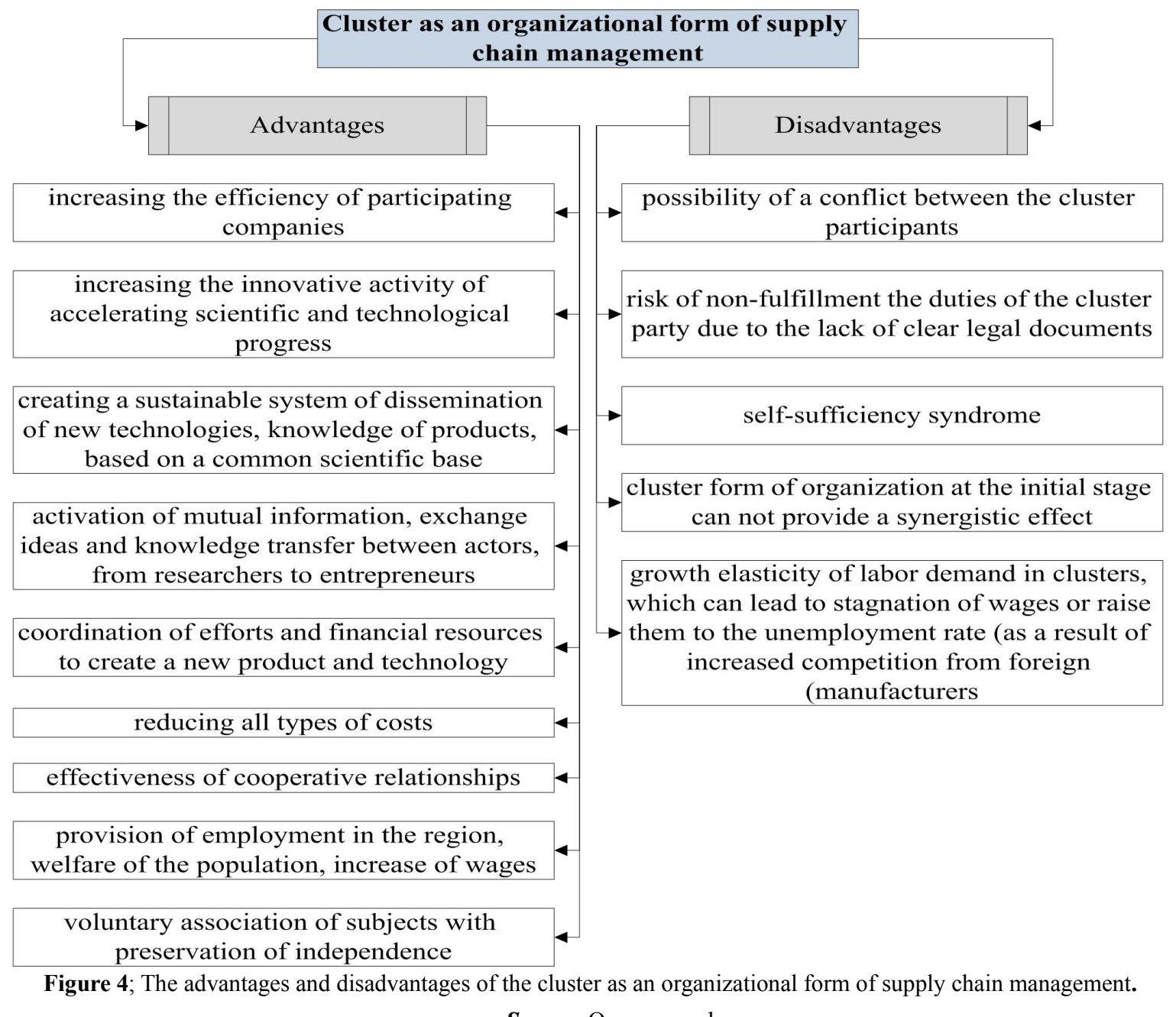

\section{Efficiency of cluster structures}

\subsection{Synergistic effect of cluster structures functioning}

The synergetic effect of the cluster structures functioning is the result of appearance, first of all, two characteristic properties of clusters as varieties of logistics systems: first, it is the symbiosis of cluster entities ${ }^{[4]}$, and, secondly, its innovative nature.

A specific feature of clusters, as a kind of logistics systems, is the economic symbiosis, that is, the coexistence of different economic entities, which provides the cluster structures with a synergistic effect. Depending on the nature of the partners interaction in the cluster structures, there are three types of symbiosis: mutatism (lat. mutuus) - each of the participants brings other relevant benefits; commensalism (lat. commensal) - one symbiont uses (consumes) the remnants of the production of another; protocooperation - joint existence is profitable, but not obligatory. 
Economic symbiosis in TLC contributes to ensuring such interaction of business structures, which results in a significant increase in the economic effect. In addition, the symbiotic relationship lies in the distribution of a new form of cooperation in logistics systems of an innovative type - networking.

Transport-logistics clusters, as noted above, belong to innovative clusters. The formation of innovative transport-logistics clusters is an opportunity for an effective restructuring of the economy to reach the new level of world economic relations. Innovation cluster, being the key point in the growth of an innovative market economy, allows us to take advantage of two ways of coordinating the economic system - the intra-firm hierarchy and the market mechanism, which enables more quickly and efficiently to distribute new knowledge, scientific discoveries and inventions; focus on business processes that provide the most added value by transferring the rest to outsourcing; to effectively attract and use investments; to achieve a multiplier effect from the dissemination of information within the innovation cluster.

An analysis of the international and domestic experience of transport-logistics cluster functioning can reveal a synergistic effect from the interaction of all its participants, which is formed by:

- $\quad$ sharing of infrastructure objects and all kinds of resources;

- centralization of information flows;

- $\quad$ activating the introduction and use of intelligent transport systems;

- reduction of transaction costs;

- centralization of educational, research and innovation activities;

- $\quad$ providing integrated security of supply chains;

- coordination with state authorities;

- $\quad$ increasing the investment and innovation activity of cluster participants.

\subsection{Sources in creating synergies TLC}

Another feature of the transport-logistics cluster is its dual nature. Duality is explained by the possibility of considering TLC: first, as an infrastructure element (protocluster) of the economic cluster; and secondly as an independent form of cluster integration.

In the first case, a logistics cluster provides leak flow processes between manufacturers' strategically important area for the specific goods and the associated activities of consumers and other infrastructure entities. In this case, the task of the logistics protocluster is to ensure the interaction of elements of the cluster organization in order to increase the competitiveness of each cluster participant based on the benefits of synergistic properties. Sources of synergies in the creation of the logistics cluster are:

- $\quad$ centralization of research work (market research, innovation research, marketing research, etc.);

- financial savings by reducing transaction costs;

- complementarity in the field of R\&D;

- $\quad$ economy, due to a scale of activity;

- $\quad$ sharing of territorial tangible and intangible resources.

The efficient functioning of the cluster provides its participants with certain additional benefits presented in Figure

5. 


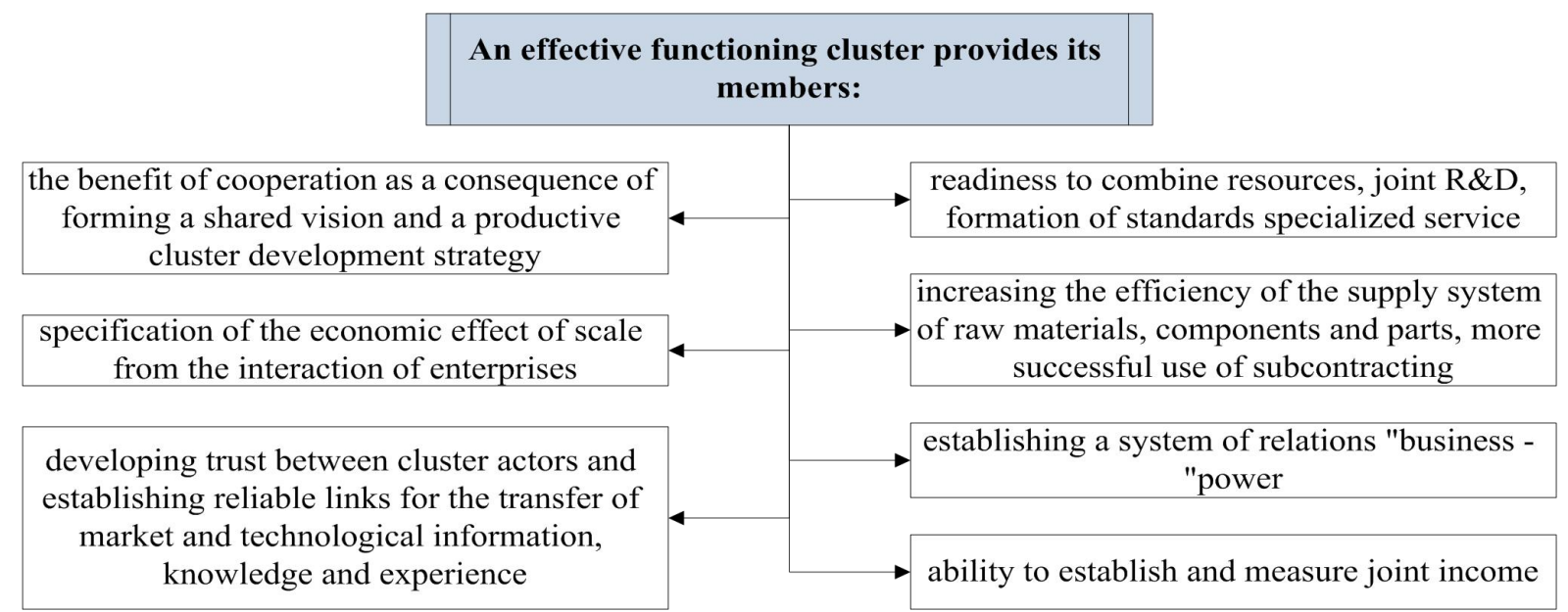

Figure 5; Benefits for participants from cluster operation

\subsection{The effect of "added value" in cluster structures}

\section{Source: Own research}

The main competitive advantage of cluster model of supply chain management is to create in clusters, the so-called "value added," or the formation of a new value at the expense of the synergistic effect, that is, the accumulation and interconnection of the resource that exists. In the modern economy, the main advantage and the main source of efficiency is an innovation in any form that meets industry requirements: a new method, a new quality of service, a new style, new knowledge, etc. The "new" is today the undisputed attribute of economic leadership and evidence of growth and forward movement, which ensures the implementation of a cluster model of development; new quality of transport and logistics services is formed in TLC. The transport-logistics cluster consists of enterprises performing different functions, but they are united by one technological process - transportation and delivery of goods from producers to their consumers, the result of which is an integrated product - reliable and high-quality transport service, created by the efforts of all members of the cluster, ranging from those involved in scientific development and training, and ending with transport companies and logistics intermediaries.

The logistics cluster, as an independent form, is formed to manage technological chains from suppliers of raw materials and production companies to consumers who interact with each other within the framework of a single chain of value creation and an increase of logistics potential of a certain territory, which promotes the development of this territory.

Tasks that facilitates logistics cluster infrastructure as part of the economic cluster and independent form shown are presented in Figure 6.

As an infrastructure element of an economic cluster or an independent form of cluster integration, transport-logistics cluster remain the organizational form of consolidating the efforts of stakeholders to achieve competitive advantages in a globalizing economy and represent a vivid example of multifunctional and multidimensional dependencies. 


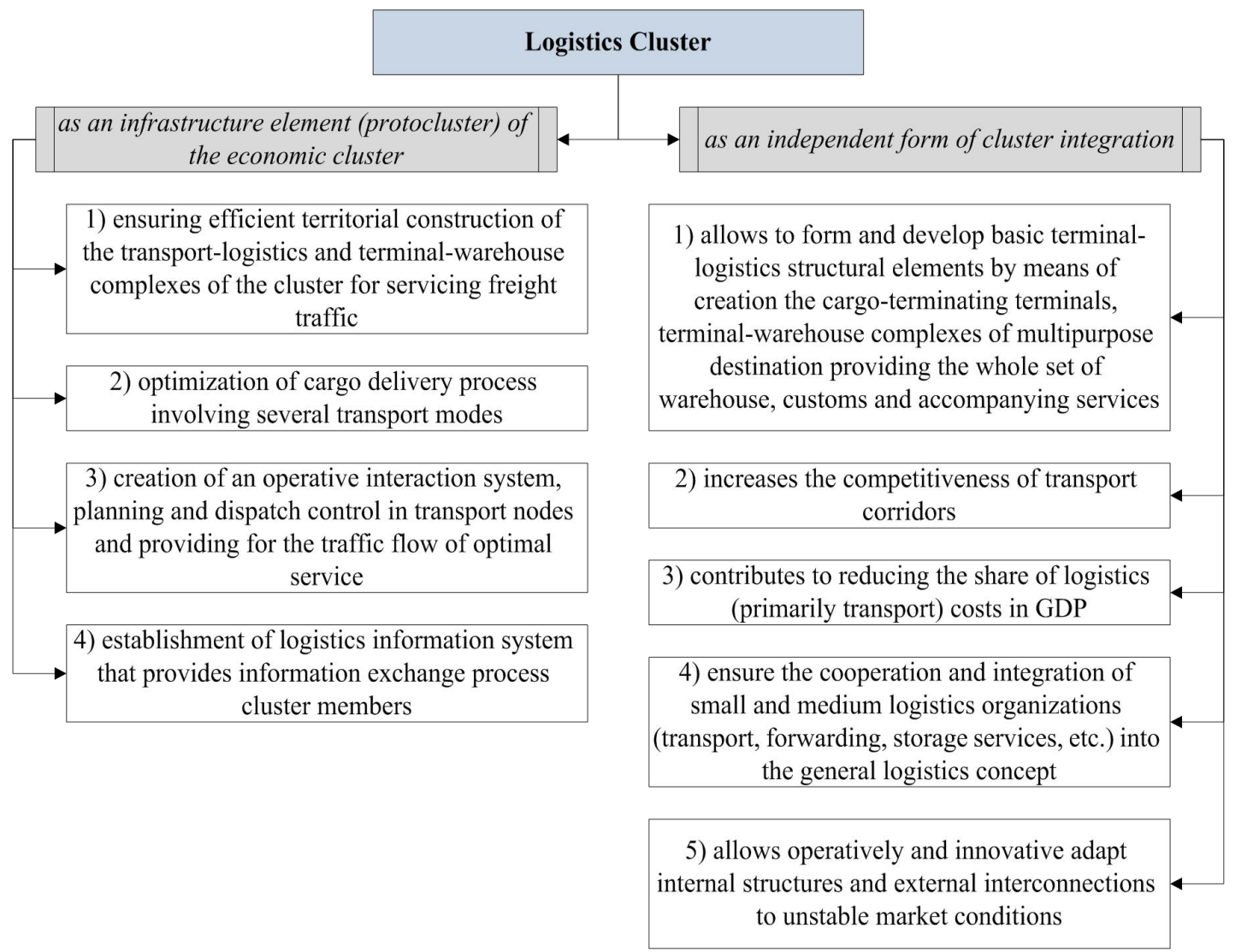

Figure 6; Task (expected result) of the transport-logistics cluster under different forms of consideration

\section{Conclusions}

Source: Own research

As a result of global changes in the global competitive environment significantly evolves the cluster theory. The conceptual vision of the essence of cluster structures changes. Clusters in the current conditions of informatization and intellectualization of economic systems, lose one of its main features - territorial identity. Today cluster should be considered as an organizational form of supply chain management, which ensures the formation of advanced and competitive supply chains, creating additional customer value in the integrated supply chain and obtain synergies from cluster interaction.

The main competitive advantage of cluster structures should consider its ability to optimize the relationship and save all kinds of costs, access to resources and competencies of partners and growth of innovation activity, which is achieved by building an effective partnership interaction around the technological chain of competitive goods production and the formation of its additional consumer value. In addition, cluster form of business organization differs from other integrated structures with its flexibility, dynamism, and democratized structure in which the team management methods are replaced by market mechanisms mutually beneficial cooperation.

Particular importance in ensuring the competitiveness of supply chains belongs to transport-logistics clusters, which, on the one hand, act as an independent form of cluster integration and contribute to the innovative development of the transport-logistics industry, and, on the other hand, are protocluster and provide the development of transport-logistics infrastructure, which is the basis for the economic systems development.

For Ukraine, which has enormous transit potential, the TLC development has a strategic importance, although the formation of the organizational and managerial mechanism of innovative development of transport-logistics infrastructure based on cluster structures in the country is at an initial stage of formation, experiencing significant economic, political and social barriers. Overcoming these barriers requires the development of cluster initiatives, further research methodological aspects, organizational and legal aspects and features of transport-logistics clusters formation 
as an effective organizational form of the perfect supply chain formation.

To sum up, companies must learn to think in terms of "cluster interactions" and practice integrate the efforts of various countries to optimize the processes of creating value and achieving competitiveness not only its own business but integrated supply chains, in which their activities are integrated.

\section{References}

1. Natsionalna transportna stratehiia Ukrainy na period do 2030 roku [The national transport strategy of Ukraine for the period up to 2030] // [Electronic resource]. - Available at: https://mtu.gov.ua/news/28581.html (in Ukrainian).

2. Marshall A. Printsipyi ekonomicheskoy nauki perevoda [Principles of Economic Science] // [Electronic resource]. - Available at: http://eteor.at.ua/_ld/0/20_HFk.pdf (in Ukrainian).

3. Porter ME. Konkurentsiia [Competition], Moscow: Williams Publishing House 2005; 608 p. (in Russian).

4. Smerichevska SV, Fedorov EE, Ibrahimkhalilova TV. Stratehiia formuvannia ta rozvytku transportno-lohistychnykh klasteriv v Ukraini: innovatsiino-intelektualnyi pidkhid [Strategy of formation and development of transport-logistics clusters in Ukraine: innovative-intellectual approach], [Monograph], Donetsk: "BIK" 2013; p. 360 (in Ukrainian).

5. Artamonova N, Chernat A. Transportno-lohistychna klasteryzatsiia yak faktor zabezpechennia innovatsiinoho rozvytku rehioniv Ukrainy [Transport-logistics clusterization as a factor for providing innovative development of the regions of Ukraine] // Proceedings of the Odessa National Economic University, 2014; 9: 43-57 (in Ukrainian).

6. Karpenko OO. Yevropeiskyi vektor klasteryzatsii transportno-lohistychnykh pidpryiemstv u ploshchyni informatsiino-komunikatsiinykh tekhnolohii [European vector of clustering of transport and logistics enterprises in the field of information and communication technologies], [Monograph], Kyiv: TOV «SIK HRUP Ukraina» 2017; p. 252. (in Ukrainian).

7. Palyvoda OM. Orhanizatsiino-upravlinski zasady innovatsiinoho rozvytku promyslovosti na osnovi merezhevykh struktur: teoriia, metodolohiia, praktyka [Organizational and managerial principles of innovation development of industry on the basis of network structures: theory, methodology, practice], [Monograph], Kyiv: Condor Publishing House 2017; p.360(in Ukrainian).

8. National Economic Development and Modernization: Experience of Poland and Prospects for Ukraine [Monograph]. Kielce, Poland: "Izdevnieciba "Baltija Publishing”, 2017; pp.63-77.

9. Mezhfirmennaya kooperatsiya: analiz razvitiya klasterov v Rossii [Inter-firm cooperation: analysis of the clusters development in Russia] // [Electronic resource]. - Available at: http://www.rjm.ru/files/upload/rjm/2010/rmj_1_10_golovanova_avdasheva_kadochnikov.pdf (in Russian).

10. Poliakova OM., Shramenko OV. Suchasni tendentsii rozvytku transportno-lohistychnoi infrastruktury v Ukraini i sviti [Modern trends in the development of transport and logistics infrastructure in Ukraine and in the world] // Proceedings of the Economy of Transport and Industry 2017; 58: 126-134 (in Ukrainian).

11. Onyshko SV. Derzhavne rehuliuvannia klasteryzatsii ekonomiky yak napriamok rozbudovy natsionalnoi innovatsiinoi modeli [State regulation of clusterization of the economy as a direction of development of a national innovation model] // Actual problems of the economy, 2010; 11: pp.55-61 (in Ukrainian).

12. Smyrnov I. Transportno-lohistychni klastery v ES ta intehratsiia Ukrainy v tsi struktury [Transport and logistics clusters in the EU and integration of Ukraine into these structures] // Actual problems of economic and social development of the region, 2012; pp.219-222 (in Ukrainian).

13. Hosudarstvennoe rehulyrovanye razvytyia klasterov v Ukrayne [State regulation of cluster development in Ukraine] // [Electronic resource]. - Available at: http://www.nbuv.gov.ua/old_jrn/ Soc_Gum/Vchnu_ekon/2009_3_1/pdf/034-039.pdf(in Russian).

14. Smyrnov I, Shmatok O. Formuvannia transportno-lohistychnykh klasteriv u ES: ukrainskyi kontekst [Formation of transport and logistics clusters in the EU: Ukrainian context] // Proceedings of the T.Shevchenko Kyiv National University, Series "Geography" 2012; 60: 14-19 (in Ukrainian). 